\title{
PENGELOLAAN APLIKASI PENILAIAN KINERJA GURU DI SMK NEGERI 2 SRAGEN BERBASIS WEB
}

\author{
Wawan Yulianto \\ SMK Negeri 2 Sragen \\ Wawanyulianto80@gmail.com
}

\begin{abstract}
Abstrak. Penelitian ini bertujuan untuk 1) membangun Aplikasi berbasis Web untuk mempermudah Penilaian Kinerja Guru secara online di SMK Negeri 2 Sragen; dan 2) mengetahui kelayakan sistem aplikasi berbasis Web dalam Penilaian Kinerja Guru secara online di SMK Negeri 2 Sragen.

Jenis penelitian ini adalah Penelitian dan Pengembangan.Pengumpulan data menggunakan teknik wawancara, angket (kuisioner), observasi dan dokumentasi.Kelayakan website ini dilakukan dengan alpha testing dan beta testing. Alpha testing dilakukan dengan meminta pendapat dan validasi tim ahli Teknik Informasi Komunikasi dan ahli materi konten Penilaian Kinerja Guru sedangkan beta testing dilakukan dengan meminta pendapat kepada user yaitu para guru yunior yang dinilai dalam pelaksanaan Penilaian Kinerja Guru. Analisis data hasil kelayakan dilakukan dengan menggunakan bantuan skala Likert yang diolah secara kualitatif dalam bentuk persentase.

Hasil penelitian adalah 1) aplikasi Penilaian Kinerja Guru di SMK Negeri 2 Sragen dikembangkan melalui tahapan-tahapan : Studi Pendahuluan (analisis kebutuhan dan mengumpulkan informasi); Pembuatan dan pengembangan produk awal (mendesain produk awal, validasi desain, dan revisi produk awal); Uji coba dan revisi produk (Uji coba secara terbatas dan Uji coba luas ) sehingga diperoleh produk akhir. 2) Website aplikasi Penilaian Kinerja Guru di SMK Negeri 2 Sragen telah dinyatakan layak oleh ahli Teknik Informasi Komunikasi, ahli konten materi Penilaian Kinerja Guru, dan para user guru yunior yang dinilai dalam pelaksanaan Penilaian Kinerja Guru online.
\end{abstract}

Kata kunci: pengelolaan, penilaian kinerja guru, web.

Abstract. This study aims to 1) build Web-based Applications to facilitate the Performance Appraisal of Teachers online at SMK Negeri 2 Sragen; and 2) to know the feasibility of Web-based application system in Teacher Performance Assessment online at SMK Negeri 2 Sragen.

This type of research is Research and Development. Data collection using interview technique, questionnaire (questionnaire), observation and documentation. The feasibility of this website is done with alpha testing and beta testing. Alpha testing is done by requesting the opinion and validation of the team of Information Communication Technician and content material expert of Teacher Performance Assessment while beta testing is done by asking the opinion to the user that the junior teachers are assessed in the implementation of Teacher Performance Assessment. Analysis of feasibility data is done by using Likert scale aid which is processed qualitatively in the form of percentage.

The results of the research are 1) the application of Teacher Performance Appraisal in SMK Negeri 2 Sragen developed through the stages: Introduction study (needs analysis and information gathering); Preparation and development of the initial product (designing initial product, design validation, and initial product revision); Trial and product revision (Trial is limited and Test area) to obtain the final product. 2) The Website of the Performance Appraisal Appraisal of Teachers at SMK Negeri 2 Sragen has been declared eligible by the Information Communication Technician, the material content expert of the 
Teacher Performance Assessment, and the junior teacher users assessed in the implementation of the online Teacher Performance Assessment.

\section{Keywords : management, teacher performance evaluation, web}

\section{PENDAHULUAN}

Mendidik bukanlah tugas yang sederhana, pendidik yang sesungguhnya harus mampu membawa orang lain seperti halnya peserta didik beranjak dari kegelapan menuju sutu pencerahan yang terang benderang, dengan demikian istilah guru memiliki konotasi yang agung karena dalam ajaran agama Islam salah satu fungsi $(r a b b)$ atau rububiyah Tuhan adalah guru. Sehingga guru adalah manusia unggul yang mampu beradaptasi dan melakukan trnasformasi diri dan senantiasa bergelut dari suatu perbaikan ke perbaikan yang lain (Suyono dan Hariyanto, 2012:189).

Tugas guru sebagai suatu profesi adalah mendidik dan mengajar, sebagai pendidik, guru mengemban tugas meneruskan dan mengembangkan nilainilai hidup kepada anak didik dan tugas guru sebagai pengajar berarti meneruskan dan mengembangkan ilmu pengetahuan dan teknologi kepada anak didik.Sebagai pengajar, guru membantu peserta didik yang sedang berkembang untuk mempelejari sesuatu yang belum diketahuinya, membentuk kompetensi, dan memahami materi standar yang dipelajari (Mulyasa, 2013:38). Sehingga tidak berlebihan jika guru dikatakan sebagai profesi yang tidak boleh berhenti belajar, ini karena belajar adalah kata kunci dari tiga hal penting bagi profesi guru yaitu paradigma, cara, dan komitmen (Chatib, 2012:64).

Penilaian Kinerja Guru dilakukan terhadap kompetensi guru sesuai dengan tugas pembelajaran, pembimbingan, atau tugas tambahan yang relevan dengan fungsi sekolah atau madrasah. Khusus untuk kegiatan pembelajaran atau pembimbingan, kompetensi yang dijadikan dasar untuk penilaian kinerja guru adalah kompetensi pedagogik, profesional, sosial dan kepribadian, sebagaimana ditetapkan dalam Peraturan Menteri Pendidikan nasional Nomor 16 Tahun 2007.Keempat kompetensi ini telah dijabarkan menjadi kompetensi guru yang harus dapat ditunjukkan dan diamati dalam berbagai kegiatan, tindakan dan sikap guru dalam melaksanakan pembelajaran atau pembimbingan.Sementara itu, untuk tugas tambahan yang relevan dengan fungsi sekolah atau madrasah, penilaian kinerjanya dilakukan berdasarkan kompetensi tertentu sesuai dengan tugas tambahan yang dibebankan tersebut (misalnya; sebagai kepala sekolah atau madrasah, wakil kepala sekolah atau madrasah, pengelola perpustakaan, dan sebagainya).

Mengingat urgensi Penilaian Kinerja Guru maka dalam pelaksanaannya diperlukan kesungguhan dari semua stake holder terkait dan akan semakin comfortable jika ditopang dengan teknologi yang mampu mensupport kegiatan Penilian Kinerja Guru misalnya teknologi informasi yang berbasis jejaring (web, blok, media online dan sebagainya). Pada era modern sekarang ini penggunaan teknologi mutlak diperlukan, terutama untuk pelayanan informasi dituntut cepat, akurat selalu update bisa diakses dimana dan kapan saja menggunakan peralatan 
sepraktis mungkin serta pelayanan 24 jam, termasuk dalam hal penilaian kinerja guru.

\section{METODE PENELITIAN}

\subsection{Jenis Penelitian}

Penelitian ini bersifat pengembangan dari model konvensional manual dirubah menjadi system penilaian (Penilaian Kinerja Guru) yang berbasis web secara online sehingga penelitian ini merupakan pengembangan atau Research and Development. Menurut Sutama (2015:183) bahwa penelitian dan pengembangan atau research and development $(\mathrm{R} \& \mathrm{D})$ adalah sebuah strategi penelitian yang cukup ampuh untuk memperbaiki praktik. Penelitian dan pengembangan adalah suatu proses atau langkah-langkah untuk mengembangkan suatu produk baru atau menyempurnakan produk yang telah ada yang dapat dipertanggungjawabkan. Produk tersebut tidak selalu berbentuk benda atau perangkat keras (hardware) seperti buku, modul tetapi bisa juga perangkat lunak (software) seperti program computer untuk pengolah data.

\subsection{Waktu danTempat Penelitian}

Penelitian dilakukan pada semester ganjil tahun ajaran 2017/2018 dengan lokasi di SMK Negeri 2 Sragen dengan alamat Jln. dr. Sutomo No. 04 kampung Beloran Sragen Kulon, Sragen.

\subsection{ProsedurPengembangan}

Pengembangan Penilaian kinerja guru berbasis Web dalam penelitian ini memodifikasi penelitian pengembangan Borg \& Gall. Prosedur yang dimaksud peneliti meliputi 4 tahapan pokok, yaitu 1. Studi Pendahuluan, terdiri dari : a) Analisis Kebutuhan, b). Mengumpulkan Informasi (Studi Literatur dan Survei Lapangan), 2. Pembuatan dan pengembangan produk awal, terdiri dari : a) Mendesain produk awal (model proto type) berdasar studi pendahuluan, b). Validasi desain produk awal (model proto type) oleh pakar, c) Revisi produk awal (model proto type) berdasar hasil validasi oleh pakar, 3. Uji coba dan revisi produk, terdiri dari a) Uji coba produk awal secara terbatas dilanjutkan analisis dan revisi, b) Uji coba luas dilanjutkan analisis dan revisi, dan 4. Produk akhir.

\subsection{Teknik Pengumpulan Data}

Sugiyono (2016:137) menjelaskan bahwa pengumpulan data dapat dilakukan dalam berbagai setting, sumber, dan berbabagai cara. Selanjutnya apabila dilihat dari segi cara atau teknik pengumpulan data, maka teknik pengumpulan data dapat dilakukan dengan interview (wawancara), kuisioner (angket), observasi (pengamatan), dan gabungan ketiganya. Dalam penelitian ini, teknik pengumpulan data yang dilakukan adalah 1) wawancara dengan instrumen pedoman wawancara, 2)Angket atau kuesioner dengan instrument butir-butir pertanyaan kuis/angket, 3) Observasi dengan instrument lembar observasi, dan 4) dokumentasi dengan instrument atau alat tulis kantor, photo, dan kamera.

\subsection{Keabsahan Data}

Keabsahan data menggunakan uji credibility (validitas internal) dan transferability (validitas eksternal).

\subsubsection{Uji credibility (validitas internal)}

Metode peningkatan ketekunan sebagai alternatif dalam uji credivility. Meningkatkan ketekunan berarti melakukan pengamatan secara lebih cermat dan berkesinambungan dengan cara tersebut maka kepastian data dan urutan peristiwa akan dapat direkam secara pasti dan sistematis (Sugiyono, 2016:272). 


\subsubsection{Uji transferability (validitas eksternal)}

Validitas eksternal menunjukkan derajat ketepatan maka peneliti dalam membuat lapaorannya harus memberikan uraian yang rinci, jelas, sistematis, dan dapat dipercaya. Dengan demikian maka pembaca menjadi jelas atas hasil penelitian tersebut, sehingga dapat memutuskan dapat atau tidaknya untuk mengaplikasikan hasil penelitian tersebut di tempat lain (Sugiyono, 2016:272)

\subsection{Teknik Analisis Data}

Teknik analisis data dilakukan pada pengambilan data menggunakan kuesioner untuk menguji kualitas website Penilaian Kinerja Guru. Penelitian ini mengambil data dari ahli (Teknik Informatika dan Komunikasi), ahli materi, tim penilai Penilaian Kinerja Guru dan guru yang dinilai dalam kegiatan PKG. Data yang dihasilkan dari kuesioner tersebut merupakan gambaran pendapat atau persepsi pengguna website Penilaian Kinerja Guru. Data yang dihasilkan dari kuesioner tersebut merupakan data kuantitatif kemudian dikonversi ke dalam data kualitatif dalam bentuk interval menggunakan Skala Likert (1 s.d 5)

$$
\text { Persentase kelayakan }(\%)=\frac{\text { skoryangdiobservasi }}{\text { skormaksimal }} \times 100 \%
$$

Hasil perhitungan di atas kemudian digunakan untuk menentukan kelayakan website Penilaian Kinerja Guru. Klasifikasi dibagi menjadi lima kategori pada skala likert. Berikut merupakan pembagian rentang kategori kelayakan website.

Tabel 1. Kategori Kelayakan Produk (Website PKG)

\begin{tabular}{|c|c|}
\hline Kategori & Presentase \\
\hline Sangat Layak & $81 \%-100 \%$ \\
\hline Layak & $61 \%-80 \%$ \\
\hline Cukup Layak & $41 \%-60 \%$ \\
\hline Tidak Layak & $21 \%-40 \%$ \\
\hline Sangat Tidak Layak & $0 \%-20 \%$ \\
\hline
\end{tabular}

3. HASIL PENELITIAN DAN PEMBAHASAN

\subsection{Model penilaian Kinerja Guru} selama ini di SMK Negeri 2 Sragen

Pelaksanaan Penilaian Kinerja Guru di SMK Negeri 2 Sragen selama ini masih bersifat konvensional atau manual maksudnya seluruh tahapan Penilaian Kinerja Guru dari persiapan, pelaksanaan hingga pelaporan hasil penilaian dilakukan secara manual dan belum menggunakan system online berbasis website. Kegiatan Penilaian Kinerja Gurudi SMK Negeri 2
Sragen selama ini dilakukan 2 (dua) kali setahun, yaitu pada awal tahun pelajaran (penilaian formatif) dan akhir tahun pelajaran (penilaian sumatif).

Kegiatan penilaian kinerja guru pembelajaran atau pembimbingan dilaksanakan dalam 4 (empat) tahapan pokok, yaitu persiapan, pelaksanaan, pemberian nilai, dan pelaporan yang secara keseluruhan dilakukan secara manual dan harus bertatap muka.Setelah nilai kinerja guru diperoleh, penilai wajib memberitahukan hasilnya kepada guru 
yang dinilai dan penilei juga memiliki kewajiban melaporkan hasil kepada pihak yang berwenang untuk menindaklanjuti hasil penilaian kinerja guru tersebut. Hasil penilaian kinerja guru formatif dilaporkan kepada kepala sekolah dan coordinator penilaian kinerja guru berkelanjutan sebagai masukan untuk merencanakan kegiatan penilaian kinerja berkelanjutan tahunan. Sedangkan hasil penilaian kinerja guru sumatif dilaporkan kepada tim penilai tingkat kabupaten/kota, provinsi, atau pusat sesuai dengan kewenangannya

\subsection{Pengembangan Penilaian Kinerja} Guru berbasis Website dalam Penilaian Kinerja Guru secara online di SMK Negeri 2 Sragen

Pengembangan sistem aplikasi Website dalam Penilaian Kinerja Guru secara online di SMK Negeri 2 Sragen mengacu pada pada prosedur pengembanganBorg \& Gall (1983:775) yang telah disesuaikan dengan situasi dan kondisi yang ada dengan tanpa mengurangi substansi dari penelitian pengembangan pada model di atas, peneliti melakukan modivikasi langkah yang telah disesuaikan untuk menghasilkan sistem penilaian kinerja guru secara online berbasis website yakni : a. Studi Pendahuluan, terdiri dari : 1) Analisis Kebutuhan, 2). Mengumpulkan Informasi (Studi Literatur dan Survei Lapangan), b. Pembuatan dan pengembangan produk awal, terdiri dari : 1) Mendesain produk awal (model proto type) berdasar studi pendahuluan, 2). Validasi desain produk awal (model proto type) oleh pakar, 3) Revisi produk awal (model proto type) berdasar hasil validasi oleh pakar, c. Uji coba dan revisi produk, terdiri dari 1) Uji coba produk awal secara terbatas dilanjutkan analisis dan revisi, 2) Uji coba luas dilanjutkan analisis dan revisi, dan d. Produk akhir berupa website aplikasi penilaian kinerja guruyang layak pakai.

3.3. Deskripsi kelayakan sistem aplikasi Website dalam Penilaian Kinerja Guru secaraonline di SMK Negeri 2 Sragen.

Penentuan kelayakan sistem aplikasi website dalam penilaian kinerja guru secara online di SMK Negeri 2 Sragen dilakukan dengan teknik alpha testing (oleh ahli TIK dan ahli meteri konten PKG) dan beta testing (tanggapan user khususnya guru yang dinilai dalam pelaksanaan penilaian kinerja guru).

\subsubsection{Data Validasi Ahli TIK (Alpha Testing 1)}

Tabel 2. Data Hasil Validasi oleh 2 Ahli TIK

\begin{tabular}{|c|l|c|c|c|c|c|}
\hline \multirow{2}{*}{ Ko } & \multicolumn{5}{|c|}{ Kriteria } & \multicolumn{5}{|c|}{ Skor Penilaian } \\
\cline { 3 - 7 } & SB & B & C & K & TB \\
\hline A. Aspek Tampilan & & & & & \\
\hline 1 & Pemakaian warna seimbang dan menarik. & & 2 & & & \\
\hline 2 & Pewarnaan tidak mengacaukan tampilan layar. & & 2 & & & \\
\hline 3 & Penggunakan karakter/huruf yang sesuai & & 2 & & & \\
\hline 4 & Kombinasi warna dan huruf serasi & & 2 & & & \\
\hline 5 & Keterbacaan dan ketepatan penempatan teks & & 1 & 1 & & \\
\hline 6 & $\begin{array}{l}\text { Tata letak keseluruhan isi kompak (saling } \\
\text { mendukung) }\end{array}$ & & 1 & 1 & & \\
\hline
\end{tabular}




\begin{tabular}{|c|l|l|l|l|l|l|}
\hline \multirow{2}{*}{ No } & \multicolumn{1}{|c|}{ Kriteria } & \multicolumn{3}{c|}{ Skor Penilaian } \\
\cline { 3 - 7 } & & SB & B & C & K & TB \\
\hline 7 & Trasnsisi slide menarik dan tidak monoton & & 2 & & & \\
\hline B. Aspek Penggunaan & & & & & \\
\hline 1 & Petunjuk penggunaan disajikan dengan jelas & & 2 & & & \\
\hline 2 & $\begin{array}{l}\text { Perintah-perintah dalam program bersifat sederhana } \\
\text { dan mudah dioperasikan }\end{array}$ & & 1 & 1 & & \\
\hline 3 & Menu dan tombol dapat digunakan secara efektif & & 2 & & & \\
\hline 4 & Perpindahan antar layar sudah tepat & & 2 & & & \\
\hline 5 & Tampilan program menarik & & 2 & & & \\
\hline 6 & Kecepatan hyperlink/action & & 2 & & & \\
\hline C. Aspek Bahasa & & 2 & & & \\
\hline 1 & $\begin{array}{l}\text { Bahasa dalam petunjuk penggunaan mudah } \\
\text { dimengerti }\end{array}$ & & & & & \\
\hline 2 & Menggunakan bahasa yang komunikatif & 1 & 1 & & & \\
\hline 3 & Bahasa yang digunakan baku dan jelas & & 1 & 1 & & \\
\hline 4 & $\begin{array}{l}\text { Kalimat yang digunakan bersifat singkat, padat, dan } \\
\text { tepat }\end{array}$ & & & & & \\
\hline
\end{tabular}

Ahli teknik informatika komunikasi memberikan penilaian website penilian kinerja guru online dilihat dari aspek tampilan, aspek penggunaan, dan aspek bahasa terkait dengan petunjuk aplikasi website. Hasil dari validasi ahli teknik informatika dan komunikasi sebagai berikut.

Tabel 3. Data Hasil Pengujian Ahli TIK

\begin{tabular}{|c|c|c|c|c|c|c|}
\hline \multirow{2}{*}{ No } & \multirow{2}{*}{$\begin{array}{c}\text { Aspek } \\
\text { Penilaian }\end{array}$} & \multirow{2}{*}{$\begin{array}{l}\text { No Butir } \\
\text { Kuis }\end{array}$} & \multicolumn{2}{|c|}{ Skor } & \multirow{2}{*}{$\begin{array}{l}\text { Jumlah Skor } \\
\text { Setiap Aspek }\end{array}$} & \multirow{2}{*}{$\begin{array}{c}\text { Skor Maksimal } \\
\text { yang Diharapkan }\end{array}$} \\
\hline & & & Ahli 1 & Ahli 2 & & \\
\hline \multirow{7}{*}{1} & \multirow{7}{*}{ TAMPILAN } & 1 & 4 & 4 & \multirow{7}{*}{54} & \multirow{7}{*}{70} \\
\hline & & 2 & 4 & 4 & & \\
\hline & & 3 & 4 & 4 & & \\
\hline & & 4 & 4 & 4 & & \\
\hline & & 5 & 3 & 3 & & \\
\hline & & 6 & 3 & 3 & & \\
\hline & & 7 & 4 & 4 & & \\
\hline \multirow{6}{*}{2} & \multirow{6}{*}{$\begin{array}{l}\text { PENGGU- } \\
\text { NAAN }\end{array}$} & 1 & 4 & 4 & \multirow{6}{*}{47} & \multirow{6}{*}{60} \\
\hline & & 2 & 4 & 3 & & \\
\hline & & 3 & 4 & 4 & & \\
\hline & & 4 & 4 & 4 & & \\
\hline & & 5 & 4 & 4 & & \\
\hline & & 6 & 4 & 4 & & \\
\hline \multirow{4}{*}{3} & \multirow{4}{*}{ BAHASA } & 1 & 4 & 4 & \multirow{4}{*}{31} & \multirow{4}{*}{40} \\
\hline & & 2 & 4 & 3 & & \\
\hline & & 3 & 5 & 4 & & \\
\hline & & 4 & 3 & 3 & & \\
\hline
\end{tabular}


Adapun hasil penilaian website penilaian kinerja guruonline oleh ahli

teknik informatika dan komunikasi, dapat diringkas sesuai tabel berikut:

Tabel 4. Analisis Hasil Pengujian Ahli TIK

\begin{tabular}{|c|l|c|c|c|c|}
\hline No & $\begin{array}{c}\text { Aspek } \\
\text { Penilaian }\end{array}$ & $\begin{array}{c}\text { Jumlah } \\
\text { Butir }\end{array}$ & $\begin{array}{c}\text { Skor } \\
\text { Ahli }\end{array}$ & $\begin{array}{c}\text { Skor Maksimal } \\
\text { yang Diharapkan }\end{array}$ & $\begin{array}{c}\text { Persentase } \\
\text { Kelayakan }\end{array}$ \\
\hline 1 & Tampilan & 7 & 54 & 70 & $77,1 \%$ \\
\hline 2 & Penggunaan & 6 & 47 & 60 & $78,3 \%$ \\
\hline 3 & Bahasa & 4 & 31 & 40 & $77,5 \%$ \\
\hline \multicolumn{2}{|c|}{ Jumlah } & $\mathbf{1 7}$ & $\mathbf{1 3 2}$ & $\mathbf{1 7 0}$ & \\
\hline \multicolumn{5}{|c|}{ Skor Rerata } & \multicolumn{5}{|c|}{} \\
\hline
\end{tabular}

Berdasarkan tabel hasil penilaian websitepenilian kinerja guru online oleh ahli teknik informatika dan komunikasi yang berjumlah dua orang, kemudian hasil skor dari kedua ahli tersebut diakumulasi dan didapat skor persentase kelayakan websitepenilaian kinerja guruonline dari aspek tampilan $77,1 \%$, aspek penggunaan $78,3 \%$ sedangkan dari aspek bahasa sebesar 77,5\%, sehingga didapat rata - rata persentase kelayakan yaitu 77,63\%. Berdasarkan kategori kelayakan maka sistem penilaian kinerja guruonline berbasis web dalam kriteria "Layak".

\subsubsection{Data Validasi Ahli Materi Konten \\ PKG (Alpha Testing 2)}

Tabel 5. Data Hasil Validasi oleh 2 Ahli Materi Konten PKG

\begin{tabular}{|c|l|l|l|l|l|l|}
\hline \multirow{2}{*}{ No } & \multicolumn{1}{|c|}{ Kriteria } & \multicolumn{3}{c|}{ Skor Penilaian } \\
\cline { 3 - 7 } & & SB & B & C & K & TB \\
\hline A. Aspek Ketepatan Isi & & & & & \\
\hline 1 & Website memuat kompetensi-kompetensi PKG & 2 & & & & \\
\hline 2 & Materi yang disajikan jelas dan sistematis & 1 & 1 & & & \\
\hline 3 & $\begin{array}{l}\text { Website memuat kolom-kolom penilaian sesuai } \\
\text { kompetensi PKG }\end{array}$ & 1 & 1 & & & \\
\hline 4 & Terdapat rekap hasil PKG secara jelas & 2 & & & & \\
\hline 5 & $\begin{array}{l}\text { Terdapat informasi referensi materi penilaian yang } \\
\text { disajikan }\end{array}$ & & 2 & & & \\
\hline 6 & Website menyajikan isi PKG dengan jelas & & 2 & & & \\
\hline 7 & $\begin{array}{l}\text { Isi/materi website secara keseluruhan memiliki } \\
\text { konsep yang benar (sesuai peraturan yg berlaku). }\end{array}$ & & 2 & & & \\
\hline B. Aspek Penggunaan & & & & & \\
\hline 1 & $\begin{array}{l}\text { Penyajian materi dan hasil penilaian familiar } \\
\text { dengan pengguna (user friendly) }\end{array}$ & 1 & 1 & & & \\
\hline 2 & $\begin{array}{l}\text { Menyajikan petunjuk kegiatan yang dilakukan } \\
\text { penilai dan guru yang dinilai }\end{array}$ & & 2 & & & \\
\hline
\end{tabular}




\begin{tabular}{|c|l|c|c|c|c|c|}
\hline \multirow{2}{*}{ No } & \multicolumn{1}{|c|}{ Kriteria } & \multicolumn{4}{|c|}{ Skor Penilaian } \\
\cline { 3 - 7 } & SB & B & C & K & TB \\
\hline 3 & $\begin{array}{l}\text { Website memuat kegiatan penilaian (penilai dan } \\
\text { guru yang dinilai) }\end{array}$ & & 2 & & & \\
\hline 4 & $\begin{array}{l}\text { Website memfasilitasi guru yang dinilai untuk } \\
\text { melakukan evaluasi diri }\end{array}$ & & 2 & & & \\
\hline 5 & $\begin{array}{l}\text { Website memfasilitasi penilai dan guru yang dinilai } \\
\text { untuk berkomunikasi }\end{array}$ & 1 & 1 & & & \\
\hline
\end{tabular}

Tabel 6. Data Hasil Pengujian Ahli Materi Konten PKG

\begin{tabular}{|c|c|c|c|c|c|c|}
\hline \multirow[t]{2}{*}{ No } & \multirow{2}{*}{$\begin{array}{c}\text { Aspek } \\
\text { Penilaian }\end{array}$} & \multirow{2}{*}{$\begin{array}{c}\text { No } \\
\text { Butir } \\
\text { Kuis }\end{array}$} & \multicolumn{2}{|c|}{ Skor } & \multirow{2}{*}{$\begin{array}{l}\text { Jumlah Skor } \\
\text { Setiap Aspek }\end{array}$} & \multirow{2}{*}{$\begin{array}{c}\text { Skor Maksimal } \\
\text { yang } \\
\text { Diharapkan }\end{array}$} \\
\hline & & & $\begin{array}{c}\text { Ahli } \\
1\end{array}$ & Ahli 2 & & \\
\hline \multirow{7}{*}{1} & \multirow{7}{*}{$\begin{array}{l}\text { Ketepatan } \\
\text { Isi }\end{array}$} & 1 & 5 & 5 & \multirow{7}{*}{60} & \multirow{7}{*}{70} \\
\hline & & 2 & 4 & 4 & & \\
\hline & & 3 & 4 & 4 & & \\
\hline & & 4 & 5 & 5 & & \\
\hline & & 5 & 4 & 4 & & \\
\hline & & 6 & 4 & 4 & & \\
\hline & & 7 & 4 & 4 & & \\
\hline \multirow{5}{*}{2} & \multirow{5}{*}{$\begin{array}{l}\text { PENGGU- } \\
\text { NAAN }\end{array}$} & 1 & 5 & 4 & \multirow{5}{*}{42} & \multirow{5}{*}{50} \\
\hline & & 2 & 4 & 4 & & \\
\hline & & 3 & 4 & 4 & & \\
\hline & & 4 & 4 & 4 & & \\
\hline & & 5 & 5 & 4 & & \\
\hline
\end{tabular}

Adapun hasil penilaian website materi/konten penilaian kinerja guru, adalah penilaian kinerja guru online oleh ahli sebagai berikut:

Tabel 7. Analisis Hasil Pengujian Ahli Materi Konten PKG

\begin{tabular}{|c|l|c|c|c|c|}
\hline No & $\begin{array}{c}\text { Aspek } \\
\text { Penilaian }\end{array}$ & $\begin{array}{c}\text { Jumlah } \\
\text { Butir }\end{array}$ & $\begin{array}{c}\text { Skor } \\
\text { Ahli }\end{array}$ & $\begin{array}{c}\text { Skor Maksimal yang } \\
\text { Diharapkan }\end{array}$ & $\begin{array}{c}\text { Persentase } \\
\text { Kelayakan }\end{array}$ \\
\hline 1 & Ketepatan Isi & 7 & 60 & 70 & $85,7 \%$ \\
\hline 2 & Penggunaan & 5 & 42 & 50 & $84 \%$ \\
\hline \multicolumn{2}{|r|}{ Jumlah } & $\mathbf{1 2}$ & $\mathbf{9 2}$ & $\mathbf{1 2 0}$ & $\mathbf{8 4 , 8 5 \%}$ \\
\hline \multicolumn{2}{|r|}{ Skor Rerata } \\
\hline
\end{tabular}

Berdasarkan tabel hasil penilaian website penilaian kinerja guru online oleh ahli materi yang berjumlah dua orang diakumulasi dan didapat skor persentase kelayakan website penilaian kinerja guru online dari aspek ketepatan isi $85,7 \%$ dan dari aspek penggunaan $84 \%$ sehingga didapat rerata persentase kelayakan yaitu $84,85 \%$. Berdasarkan kategori kelayakan maka sistem penilaian kinerja guruonline berbasis web dalam kriteria "Layak". 


\subsubsection{Data Pengujian pada User (Tanggapan User/Beta Testing)}

Tabel 8. Data Tanggapan User (52 guru yunior yang dinilai)

\begin{tabular}{|c|l|c|c|c|c|c|}
\hline \multirow{2}{*}{ No } & \multicolumn{1}{|c|}{ Kriteria } & \multicolumn{3}{|c|}{ Skor Penilaian } \\
\cline { 3 - 8 } & \multicolumn{1}{|c|}{ SB } & B & C & K & TB \\
\hline A. Dimensi Usabilitas & & & & & \\
\hline 1 & Website mudah dioperasikan & 15 & 25 & 12 & - & - \\
\hline 2 & Website memiliki kemudahan navigasi & 13 & 21 & 18 & - & - \\
\hline 3 & Website memiliki link di setiap unit kerjanya & 10 & 20 & 22 & - & - \\
\hline 4 & Website memiliki tampilan yang menarik & 12 & 18 & 22 & - & - \\
\hline 5 & Website dapat menambah pengetahuan & 11 & 31 & 10 & - & - \\
\hline 6 & Koneksi web site dapat diakses 24 jam /hari & 24 & 20 & 8 & - & - \\
\hline B. & Dimensi Information Quality & & & & & \\
\hline 1 & $\begin{array}{l}\text { Website menyediakan informasi yang jelas dan } \\
\text { mudah dipahami }\end{array}$ & 12 & 22 & 18 & - & - \\
\hline 2 & $\begin{array}{l}\text { Website menyediakan informasi yang dapat } \\
\text { dipercaya }\end{array}$ & 16 & 21 & 15 & - & - \\
\hline 3 & Website menyediakan informasi yang mutahir & 22 & 22 & 8 & - & - \\
\hline 4 & Website menyediakan informasi yang relevan & 9 & 18 & 25 & - & - \\
\hline 5 & $\begin{array}{l}\text { Website menyajikan informasi yang lengkap dan } \\
\text { terperinci }\end{array}$ & 9 & 21 & 22 & - & - \\
\hline 6 & $\begin{array}{l}\text { Website menyajikan informasi dalam format yang } \\
\text { sesuai dengan kebutuhan/proposional }\end{array}$ & 8 & 18 & 26 & - & - \\
\hline C. & Dimensi Service Interaction & & & & & \\
\hline 1 & Website menjamin keamanan untuk mengunduh & 10 & 19 & 23 & - & - \\
\hline 2 & Website memiliki dan menciptakan kesan personal & 22 & 24 & 6 & - & - \\
\hline 3 & $\begin{array}{l}\text { Website memiliki kemudahan untuk menarik minat } \\
\text { dan perhatian }\end{array}$ & 15 & 23 & 14 & - & - \\
\hline 4 & Website memiliki adanya suasana komunitas & 10 & 14 & 28 & - & - \\
\hline 5 & $\begin{array}{l}\text { Website memudahkan komunikasi antara penilai } \\
\text { dengan guru yang dinilai }\end{array}$ & 11 & 20 & 21 & - & - \\
\hline 6 & $\begin{array}{l}\text { Website menjamin ketepatan dan keakuratan yang } \\
\text { diberikan }\end{array}$ & 12 & 27 & 13 & - & - \\
\hline
\end{tabular}

Uji kelayakan websitepenilaian kinerja guruonline dilakukan terhadap user setelah produk dinyatakan layak oleh ahli kedua ahli tersebut. Uji coba produk dilakukan dengan mengisi kuesioner tanggapan user yaitu para guru yunior yang dinilai mencoba atau melakukan simulasi menggunakan websitepenilaian kinerja guruonline yang diujicobakan. 
Tabel 9. Hasil Uji Kelayakan Produk oleh User 52 Responden (Beta Testing)

\begin{tabular}{|c|c|c|c|c|c|}
\hline NO & $\begin{array}{c}\text { Aspek } \\
\text { Penilaian }\end{array}$ & $\begin{array}{c}\text { No } \\
\text { Butir }\end{array}$ & $\begin{array}{l}\text { Perolehan } \\
\text { Skor }\end{array}$ & $\begin{array}{l}\text { Jumlah Skor } \\
\text { Setiap Aspek }\end{array}$ & $\begin{array}{c}\text { Skor Maksimal } \\
\text { yang Diharapkan }\end{array}$ \\
\hline \multirow{6}{*}{1} & \multirow{6}{*}{ Usabilitas } & 1 & 211 & \multirow{6}{*}{1241} & \multirow{6}{*}{1560} \\
\hline & & 2 & 203 & & \\
\hline & & 3 & 196 & & \\
\hline & & 4 & 198 & & \\
\hline & & 5 & 209 & & \\
\hline & & 6 & 224 & & \\
\hline \multirow{6}{*}{2} & \multirow{6}{*}{$\begin{array}{l}\text { Information } \\
\text { Quality }\end{array}$} & 1 & 202 & \multirow{6}{*}{1210} & \multirow{6}{*}{1560} \\
\hline & & 2 & 209 & & \\
\hline & & 3 & 222 & & \\
\hline & & 4 & 192 & & \\
\hline & & 5 & 195 & & \\
\hline & & 6 & 190 & & \\
\hline \multirow{6}{*}{3} & \multirow{6}{*}{$\begin{array}{l}\text { Service } \\
\text { Interaction }\end{array}$} & 1 & 195 & \multirow{6}{*}{1223} & \multirow{6}{*}{1560} \\
\hline & & 2 & 224 & & \\
\hline & & 3 & 209 & & \\
\hline & & 4 & 190 & & \\
\hline & & 5 & 198 & & \\
\hline & & 6 & 207 & & \\
\hline
\end{tabular}

Adapun hasil tanggapan user, oleh tabel berikut: secara garis besar dapat ditunjukkan

Tabel 10Analisis Hasil Uji Kelayakan Produk oleh User (52 Responden)

\begin{tabular}{|c|c|c|c|c|c|}
\hline No & $\begin{array}{c}\text { Aspek } \\
\text { Penilaian }\end{array}$ & $\begin{array}{c}\text { Jumlah } \\
\text { Butir }\end{array}$ & $\begin{array}{c}\text { Skor } \\
\text { Responden }\end{array}$ & $\begin{array}{c}\text { Skor Maksimal } \\
\text { yang Diharapkan }\end{array}$ & $\begin{array}{l}\text { Persentase } \\
\text { Kelayakan }\end{array}$ \\
\hline 1 & Usabilitas & 6 & 1241 & 1560 & $79,55 \%$ \\
\hline 2 & $\begin{array}{l}\text { Information } \\
\text { Quality }\end{array}$ & 6 & 1210 & 1560 & $77,56 \%$ \\
\hline 3 & $\begin{array}{l}\text { Service } \\
\text { Interaction }\end{array}$ & 6 & 1223 & 1560 & $78,4 \%$ \\
\hline & Jumlah & 18 & 3674 & 4680 & \\
\hline \multicolumn{2}{|c|}{ Skor Rerata } & & & & $78,5 \%$ \\
\hline
\end{tabular}

Berdasarkan tabel hasil uji kelayakan produk website penilaian kinerja guru online oleh user yaitu 52 guru yang dinilai, dan setiap orang diberi keleluasaan untuk melakukan penilaian kemudian hasil skor dari 52 user tersebut diakumulasi dan didapat skor persentase kelayakan website penilaian kinerja guru online dari aspek usabilitas 79,55\% dan dari aspek information quality $77,56 \%$, dan dari aspek service interaction $78,4 \%$ sehingga didapat rerata persentase kelayakan yaitu $78,5 \%$. Berdasarkan kategori kelayakan pada Tabel 4.9 maka sistem penilaian 
kinerja guru online berbasis website dalam kriteria kelayakan "Layak".

Berdasarkan kategori kelayakan pada tersebut maka sistem penilaian kinerja guruonline berbasis website dalam kriteria kelayakan "Layak". Seluruh hasil penilaian yang telah dilakukan yaitu validasi ahli TIK (alpha testing 1) menyatakan bahwa produk yang dikembangkan masuk kriteri "layak", validasi ahli materi (alpha testing 2) menyatakan bahwa produk yang dikembangkan masuk kriteria "sangat layak", dan tanggpan user (beta testing) telah menyatakan bahwa produk ini dalam kriteria kelayakan "layak" sehingga secara keseluruhan dapat dinyatakan bahwa produk website aplikasi penilaian kinerja guruonline yang dikembangkan melalui penelitian ini berkriteria "layak" untuk diaplikasikan dalam pelaksanaan penilaian kinerja guru.

Kelayakan aplikasi penilaian kinerja guru sistem online berbasis web ini dapat memfasilitasi seluruh stake holders yang terkait dengan pelaksanaan penilaian kinerja guru di SMK Negeri 2 Sragen sehingga proses dan hasil dalam kegiatan penilaian kinerja gurulebih optimal. Hal ini sesuai dengan pendapat Zaki (2009:2-3) yang menyatakan bahwa dalam website, seseorang dapat dengan mudah mempublikasikan konten-konten artikel yang dikehendaki.Website dapat dikembangkan oleh perorangan, grup tertentu, institusi pendidikan, universitas, organisasi nirlaba, institusi bisnis, dan lain sebagainya.Walaupun dalam skala yang berbeda-beda namun pada hakikatnya setiap orang memiliki kesempatan membuat dan menggunakan atau memanfaatkan website untuk mencapai tujuan tertentu.

\section{PENUTUP}

\subsection{Simpulan}

Kesimpulan yang dapat diambil berdasarkan analisis dan temuan dalam penelitian yang telah selesai dilakukan adalah sebagai berikut:

4.1.1. Model Penilaian Kinerja Guru selama ini di SMK Negeri 2 Sragen adalah masih masih bersifat konvensional, seluruh tahapan penilaian kinerja guru dari persiapan, pelaksanaan hingga pelaporan hasil penilaian dilakukan secara manual dan belum menggunakan sistem online berbasis website dan masih secara keseluruhan proses mengandalkan tatap muka antara penilai dan guru yang dinilai sehingga dalam proses pelaksanaan penilaian kinerja guru masih terkendala tempat dan waktu.

4.1.2. Pengembangan sistem aplikasi Web dalam Penilaian Kinerja Guru secara online di SMK Negeri 2 Sragen terdiri dari 4 tahapan pokok yakni a. Studi Pendahuluan, terdiri dari : 1) Analisis Kebutuhan, 2). Mengumpulkan Informasi (Studi Literatur dan Survei Lapangan),b. Pembuatan dan pengembangan produk awal, terdiri dari : 1) Mendesain produk awal (model prototype) berdasar studi pendahuluan, 2). Validasi desain produk awal (model prototype) oleh pakar, 3) Revisi produk awal (model prototype) berdasar hasil validasi oleh pakar, c. Uji coba dan revisi produk, terdiri dari 1) Uji coba produk awal secara terbatas dilanjutkan analisis dan revisi, 2) Uji coba luas dilanjutkan analisis dan revisi, dan terakhir $\mathrm{d}$. Tercipta produk akhir berupa website penilaian kinerja guru dengan sistem online yang dapat diakses 24 jam sehari.

4.1.3. Kelayakan sistem aplikasi Web dalam Penilaian Kinerja Guru secara 
online di SMK Negeri 2 Sragen ditentukan oleh pengujian berlapis yaitu validasi ahli TIK, validasi ahli isi/konten penilaian kinerja guru sebagai alpha testing, dan tanggapan user sebagai beta testing. Ahli TIK (alpha testing 1) memberi penilaian pada validasi akhir dengan persentase rerata skor $77,63 \%$. dengan kategori layak, ahli materi konten penilaian kinerja guru (alpha testing 2) memberi penilaian pada validasi akhir dengan persentase rerata skor $84,85 \%$ dengan kategori "sangat layak", uji kelayakan oleh user berupa tanggapan user (beta testing) menunjukkan persentase rerata skor 78,5 $\% \%$ dengan kategori layak sehingga produk akhir berupa websitepenilaian kinerja guruonline ini layak digunakan untuk pelaksanaan penilaian kinerja guru di SMK Negeri 2 Sragen.

\subsection{Saran}

4.2.1. Aplikasi sistem penilaian kinerja guru dengan sistem online berbasis website, diharapkan digunakan sebagai sistem penilaian kinerja guruyang resmi atau baku di SMK Negeri 2 Sragen.

4.2.1.2. Pihak pengelola sekolah hendaknya bersedia memasyakatkan aplikasi sistem penilaian kinerja guru dengan sistem online berbasis website sehingga dapat menjadi rujukan pelaksanaan penilaian kinerja gurupada sekolah-sekolah yang lain.

4.2.3. Untuk seluruh Stake Holders penilaian kinerja guru (kepala sekolah, tim penilai, dan guru yang dinilai) dan seluruh pihak terkait lainnya diharapkan antusias dan dapat menggunakan aplikasi ini dengan baik sehingga pelaksanaan penilaian kinerja guru dapat berjalan dengan efektif dan effisien.

\section{DAFTAR PUSTAKA}

B. Campbell. 2015. Understanding The Teacher Performance Evaluation Process From The Perspective Of Jamaican Public School Teachers. A thesis submitted in University of Toronto

Chatib, Munif. 2012. Gurunya Manusia. Bandung: PT Mizan Pustaka

Cecilia Isidro ANIDO . 2012. Online Teaching Performance Evaluation System: A Tool For Quality Education. Eastern University Manila 1008, Philippines

Depdiknas. 2004. Undang-undang No. 14 Tahun 2005 tentang Guru dan Dosen. Jakarta : Depdiknas

Eric S. Taylor and John H. Tyler. 2011. The Effect Of Evaluation On Teacher Performance. Perth University

Gultom, Syawal. 2012. Pembinaan Dan Pengembangan Profesi Guru.Jakarta : Depdiknas

Jovan, FN. 2007. Panduan Praktis Membuat WEB dengan PHP untuk Pemula.Jakarta : Mediakita

Judith Prugh Campbell. 2013. Evaluating Teacher Performance In Higher Education: The Value Of Student Ratings. Cambridge University of London 
Mulyasa, E.2013. Menjadi Guru Profesional Menciptakan Pembelajaran Kreatif dan Menyenangkan.Bandung : Remaja Rosda Karya

Nolan Pope.2014. The Effect Of Teacher Ratings On Teacher Performance. The University of Chicago, 5107 S Blackstone Ave 1204, Chicago, Illinois, 60615.

Peraturan Menteri Negara Pendayagunaan Aparatur Negara dan Reformasi Birokrasi Nomor 16 Tahun 2009, PK GURU

Peraturan Menteri Pendidikan Nasional Nomor 16 Tahun 2007 tentang Standar Kualifikasi Akademik dan Kompetensi Guru

Sugiyono. 2016. Metode Penelitian Kuantitatif, Kualitatif, dan R\&D. Bandung : Alfabeta

Sutama. 2015. Metode Penelitian Pendidikan Kuantitatif, Kualitatif, PTK, R\&D. Kartasura : Fairuz Media

Sutisna, Dadan. 2008. Langkah Mudah Menjadi webmaster.Jakarta : Transmedia

Suyono dan Hariyanto, 2012.Belajar dan Pembelajaran (Teori dan Konsep Dasar).Bandung : Remaja Rosda Karya.

WU JING. 2013. Development Of Teaching Performance Evaluation Tool In Higher Education Using Artificial Intelligent. Thesis submitted in fulfilment of the requirements for the award of the degree of Master of Human Captical Resource Faculty Of Manufacturing Engineering And Technology Management Universiti Malaysia Pahang.

Zaki, Ali. Dkk. 2009.Kiat Jitu Membuat Website Tanpa ModalJakarta : PT Elex Media komputindo 